УДК 378.1:616.1/4

\title{
ШЛЯХИ ОПТИМІЗАЦІЇ ВИКЛАДАННЯ ЛЕКЦІЙ 3 “ОСНОВ ВНУТРІШНЬОЇ МЕДИЦИНИ” В СВІТЛІ ЗАСАД БОЛОНСЬКОЇ ДЕКЛАРАЦІї
}

\author{
М. І. Швед, Н. В. Пассчко, Л. П. Мартинюк, Л. П. Мазур, Л. П. Боднар, \\ І. В. Смачило, А. О. Боб, Л. В. Наумова, Л. В. Радецька, Т. В. Лихацька, \\ О. Л. Сидоренко
}

ДВНЗ “Тернопільський державний медичний університет імені І. Я. Горбачевського”

\section{THE WAYS OF LECTURES TEACHING OPTIMIZATION ON "BASES OF INTERNAL MEDICINE" IN THE LIGHT OF PRINCIPLES OF BOLOGNA DECLARATION}

\author{
M. I. Shved, N. V. Pasyechko, L. P. Martynyuk, L. P. Mazur, L. P. Bodnar, I. V. Smachylo, \\ A. O. Bob, L. V. Naumova, L. V. Radetska, T. V. Lyhatska, O. L. Sydorenko \\ SHEI "Ternopil State Medical University by I. Ya. Horbachevsky"
}

\begin{abstract}
Впровадження у систему освіти засад Болонської декларації передбачас застосування для навчання студентів різноманітних методів та технологій - практичних занять, лекцій та самостійної підготовки. Особливістю клінічних лекцій є використання сучасних комп'ютерних технологій, подання світових даних та власного клінічного досвіду лектора для досягнення основної мети - формування клінічного мислення у майбутніх лікарів.

Introduction into education system the principles of Bologna declaration predicts the application for the students' studies of various methods and technologies - practical employments, lectures and independent preparation. The specific feature of clinical lectures is the use of modern computer technologies, presentation of world information and own clinical experience of lecturer for achievement of main purpose - forming of clinical thought in future doctors.
\end{abstract}

Вступ. Метою Болонської системи освіти, яка впроваджується у країнах Європи вже більше 10 років, є створення європейського науково-освітнього простору, об' єднання систем навчання різних країн для забезпечення високої якості підготовки фахівців, підвищення їх конкурентоспроможності та зростання мобільності викладачів, наукових працівників та студентів [1]. Водночас, повинні враховуватися і мовні та культурні особливості країн-учасниць Болонського освітнього простору, а також накопичений досвід національних систем навчання [2].

Впровадження у систему освіти у ВНЗ України засад Болонської декларації із застосуванням кредитно-модульної системи навчання передбачає постійний пошук новітніх засобів та технологій викладання, які б забезпечили всебічну та якісну підготовку спеціалістів медичного профілю [3].

Основна частина. Згідно із робочою програмою “Основ внутрішньої медицини” для студентів 4 курсу медичного факультету передбачено викладання дисципліни у рамках одного модуля. Предмет вклю- чає такі розділи терапії, як гастроентерологія, ендокринологія, гематологія та пульмонологія, які структуровані у відповідні змістові модулі. Всього дисципліна включає 240 годин - 8 кредитів ECTS.

Згідно із основними засадами кредитно-модульної системи навчання, яка передбачає застосування різноманітних методик навчання студентів-медиків, у вказаному об'ємі навчальних годин виділено лекції - 26 годин, практичні заняття - 138 годин; на самостійну роботу студентів відводиться відповідно 30 годин.

Одним із найбільш важливих компонентів підготовки майбутніх лікарів $€$ читання їм лекцій. Робоча програма із “Основ внутрішньої медицини” передбачає подання лекційного матеріалу із найбільш поширених захворювань внутрішніх органів (табл. 1).

Слід відмітити, що для усвідомлення важливості лекцій для студентів-медиків необхідно врахувати ряд особливостей підготовки фахівців у медичних ВНЗ. Навчання студентів матеріалу не може бути суто теоретичним, воно повинне мати у своїй основі прак-

() М. І. Швед, Н. В. Пасєчко, Л. П. Мартинюк та ін. 
Таблиця 1. Перелік лекцій із предмета “Основи внутрішньої медицини” для студентів 4 курсу медичного факультету

\begin{tabular}{|c|l|}
\hline$№$ 3/п & \multicolumn{1}{|c|}{ Тема } \\
\hline 1 & $\begin{array}{l}\text { Цукровий діабет. Сучасна класифікація, етіологія, клініка, діагностика. Актуальні питання ангіо- та } \\
\text { нейропатій }\end{array}$ \\
\hline 2 & $\begin{array}{l}\text { Новітні методи лікування хворих на ЦД. Пероральні цукрознижувальні засоби, сучасні препарати } \\
\text { інсуліну та його аналоги }\end{array}$ \\
\hline 3 & Діагностичні критерії та лікування коматозних станів при цукровому діабеті \\
\hline 4 & $\begin{array}{l}\text { Захворювання щитоподібної залози. Діагноз, диференційний діагноз, профілактика та лікування } \\
\text { зоба }\end{array}$ \\
\hline 5 & $\begin{array}{l}\text { Захворювання надниркових залоз. Хронічна недостатність надниркових залоз. Гормонально-активні } \\
\text { пухлини }\end{array}$ \\
\hline 6 & $\begin{array}{l}\text { Захворювання гіпоталамо-гіпофізарної системи. Її участь в корегуванні функціональної активності } \\
\text { залоз внутрішньої секреції }\end{array}$ \\
\hline 7 & $\begin{array}{l}\text { Гастроезофагеальна рефлюксна хвороба. } \\
\text { Шлункова диспепсія та хронічні гастрити. } \\
\text { Виразкова хвороба та інші виразки шлунка та дванадцятипалої кишки }\end{array}$ \\
\hline 8 & Жовчнокам'яна хвороба, хронічний холецистит та функціональні біліарні порушення \\
\hline 9 & Хронічні захворювання тонкої кишки \\
\hline 10 & Хронічні захворювання товстої кишки: СРК та неспецифічні коліти \\
\hline 11 & Хронічні гепатити \\
\hline 12 & Цирози печінки \\
\hline 13 & Хронічні панкреатити \\
\hline 14 & Хронічні обструктивні захворювання легень \\
\hline 15 & Бронхіальна астма \\
\hline 16 & Пневмонії \\
\hline 17 & Плеврити та нагнійні захворювання легень \\
\hline 18 & Анемії \\
\hline 19 & Гострі та хронічні лейкемії \\
\hline 20 & Геморагічні діатези \\
\hline
\end{tabular}

тичне спрямування. При цьому необхідним є як орієнтування на світові та українські стандарти діагностики та лікування захворювань внутрішніх органів, на результати численних світових багатоцентрових досліджень, так і на клінічний досвід - як провідних світових клінік та вчених, так і на власні спостереження лектора.

Викладання лекцій на кафедрі внутрішньої медицини № 1 проводиться досвідченими викладачами професорами та доцентами кафедри, які окрім викладацького досвіду володіють значним особистим досвідом у певній галузі медицини. Це забезпечує подання інтегрованих даних щодо етіології, патогенезу, діагностики, терапії та профілактики терапевтичних захворювань, що $є$ наслідком детального та глибокого аналізу як даних літератури, так і клінічного досвіду викладача.

Усі лекції для студентів 4 курсу забезпечені мультимедійним супроводом. Це значно покращує сприйняття слухачами матеріалу, що подається, за рахунок не лише звукового, але й візуального сприйняття. Крім того, це дозволяє презентувати на екрані фото- графії та відеоролики. На кафедрі створені великі бази візуальних матеріалів, що дозволяє подавати студентам як класичні випадки захворювань, так і рідкісні особливості перебігу патології. При цьому викладач має змогу спрямувати студента у правильному напрямку щодо пошуку тих чи інших особливостей хвороби, що $є$ особливо важливим з огляду на необхідність постійного проведення диференційного діагнозу між захворюваннями у практичній роботі лікаря.

При поданні матеріалу важливою частиною кожної лекції є розбір особливостей етіології та патогенезу захворювань. Напрямки лікування патології також розглядаються із точки зору механізмів прогресування хвороби - це забезпечує розвиток у студентів клінічного мислення. Постійний розвиток фармацевтичної науки, щорічне знаходження нових груп лікувальних засобів вимагає від майбутніх фахівців-медиків розуміння патогенетичних принципів лікування - завдяки цьому прийшовши у практичну медицину, вони не розгубляться серед різноманіття лікувальних засобів, а зможуть адекватно їх засто- 
совувати виходячи із принципу індивідуального підходу до лікування кожного пацієнта.

Виділення “лекційного" дня у кожному навчальному тижні забезпечує студентам можливість теоретичної підготовки до кожної лекції. Для цього можна використовувати презентації лекцій та матеріали для підготовки до лекцій, які розміщені на ВЕБ-порталі університету та містять сучасні дані, які постійно оновлюються. Маючи теоретичний запас знань, студенти можуть акцентуватись на найбільш важливому матеріалі, виділити для себе основні віхи патології, а також-при прямому спілкуванні із лектором знайти відповіді на виниклі запитання.

У підготовці мабутнього лікаря важливим є постійне повторення матеріалу, актуальною $є$ і його

\section{Література}

1. Мишанич Г. І. Медична та фармацевтична освіта в умовах Болонського процесу / Г. І. Мишанич // Внутрішня медицина. -2007.--№ 3.-С. 128-131.

2. Ковальчук Л. Я. Медична освіта вУкраїні та Болонський процес : реальність і шляхи переходу до європейського інтеграція із новими знаннями, набутими на інших кафедрах. Тому доцільним виглядає розділення у часі лекцій та практичних занять із певних змістових модулів, що дозволить максимально ефективно забезпечити оволодіння студентами матеріалом, розвинути його клінічне спрямування та створити сприятливі умови для подальшої практичної діяльності.

Висновок. Застосування при викладанні лекцій сучасних комп'ютерних технологій, зіставлення світового та власного досвіду викладача, розвиток патогенетично спрямованого мислення студентів $\epsilon$ засадами ефективного оволодіння ними принципами діагностики та терапії захворювань внутрішніх органів у рамках предмета “Основи внутрішньої медицини".

освітнього простору / Л. Я. Ковальчук, І. Р. Мисула, К. О. Пашко // Медична освіта. -2005. - № 2. - С. 21-23.

3. Болонський процес і система організації практичної підготовки студентів / С. М. Нейко, Л. В. Глушко, М. І. Мізюк, І. П. Вакалюк// Медична освіта. -2007. -№ 2.-С. 56-58. 